Journal of Animal and Veterinary Advances $10(1): 1-5,2011$

ISSN: $1680-5593$

(C) Medwell Journals, 2011

\title{
Relationship Between Leptin Gene Polymorphism with Economical Traits in Iranian Sistani and Brown Swiss Cows
}

\author{
${ }^{1}$ Karim Nobari, ${ }^{1}$ Mojtaba Tahmoorespur, ${ }^{2}$ Shokoufe Ghazanfari, \\ ${ }^{1}$ Mohammad Reza Nassiry and ${ }^{3}$ Eisa Jorjani \\ ${ }^{1}$ Department of Animal Science, Faculty of Agriculture, \\ Ferdowsi University of Mashhad, Mashhad, Iran \\ ${ }^{2}$ Department of Animal and Poultry Sciences, \\ College of Aboureihan, University of Tehran, Pakdasht, Tehran, Iran \\ ${ }^{3}$ Department of Biology Science, Faculty of Science, \\ Gonbad Institute of Higher Education, Gonbad, Iran
}

\begin{abstract}
The aim of this study was to investigate leptin gene polymorphism in Sistani cows and Brown Swiss cows and relationship between it's polymorphism with economical traits in them. Blood samples were collected from Sistani cows and Brown Swiss cows. DNA was extracted from the blood samples and then it was amplified by Polymerase Chain Reaction (PCR) technique to amplify a 422 bp DNA fragment. Digestion of amplicons with BstMB1 was done on PCR product. Genotype frequencies were $0.77,0.22,0.01$ for $\mathrm{AA}, \mathrm{AB}$ and $\mathrm{BB}$, respectively in Sistani cows and $0.64,0.35$ and 0.01 for $\mathrm{AA}, \mathrm{AB}$ and $\mathrm{BB}$, respectively in Brown Swiss cows. The populations were in Hardy-Weinberg equilibrium with respect to Leptin gene. The AB genotype had a significant effect on growth traits including weight at 9 and 12 months and age at successful insemination than the other genotypes in Sistani cows. AB genotype also had a significant effect on milk production, days open and milking days compared with other genotypes in Brown Swiss cows.
\end{abstract}

Key words: Leptin, RFLP-PCR, economical traits, Sistani cows, Brown Swiss cows, insemination

\section{INTRODUCTION}

Leptin is a $16 \mathrm{Kd}$ protein that is synthesized by adipose tissue and is involved in regulation of feed intake, energy balance, fertility, reproduction, milk production as well as immune functions (Houseknecht et al., 1998; Fruhbeck, 2001). The expression and secretion of leptin is highly correlated with body fat mass and adipocyte size (Fruhbeck et al., 1998; Hossner, 1998). In cattle, the leptin gene is located on chromosome 4 and consists of 3 exons and 2 introns of which only 2 exons are translated into protein. Several polymorphims had been reported in the bovine leptin gene but only four of them changed the amino acid sequence in the encoding polypeptide (Konfortov et al., 1999; Haegeman et al., 2000; Buchanan et al., 2002; Lagonigro et al., 2003; Liefers et al., 2003).

Recently, the promoter region has been sequenced and 20 SNPs (Single Nucleotide Polymorphisms) had been found (Liefers, 2004). Wilkins and Davey (1997) reported restriction fragment length polymorphisms of the bovine leptin gene. Polymorphisms in the bovine leptin gene had been described and an association with fat deposition in beef cattle was reported (Pomp et al., 1997).
Lagonigro et al. (2003) reported association of 5 SNP bovine leptin gene with feed intake and fat-related traits. Individuals with genotype A/T at exon 2 had 19\% greater mean feed intake than individuals with genotype AA. Liefers et al. (2002) reported that heifers with the $\mathrm{AB}$ genotype produced $1.32 \mathrm{~kg}$ day $^{-1}$ more milk and consumed $0.73 \mathrm{~kg}$ day ${ }^{-1}$ more dry matter compared with the AA genotype. They suggested that B allele could yield a higher milk yield without negative affect on energy balance and fertility. Block et al. (2001) showed that leptin is negatively correlated with the amount of non esterified fatty acids which reflects the amount of fat mobilization.

As leptin could play an important role in the processes occurring during the lactation period in dairy cows. The aim of this study was to estimate the frequency of leptin gene and relationships between its polymorphism with variations in growth and age at successful insemination in an Iranian native cattle, Sistani and milk production, days open and milking days in Brown Swiss cattle.

\section{MATERIALS AND METHODS}

Animals and DNA extraction: This study took place at biotechnology laboratory in Ferdowsi University of

Corresponding Author: Karim Nobari, Department of Animal Science, Faculty of Agriculture, Ferdowsi University of Mashhad, P.O. Box 91775-1163 Mashad, Iran 
Mashhad, Iran, 2008. Blood samples were collected from 103 Iranian Sistani cattle and 104 from Brown Swiss cattle randomly. They were obtained from Animal Breeding Station in Zahak district of Zabol city and Animal Breeding Station in Torogh and Telgerd of Mashhad city, respectively. Blood was collected on $\mathrm{K}_{2}$ EDTA tubes and stored either at $-20^{\circ} \mathrm{C}$ for few weeks. DNA extraction was done on the blood samples using guanidium thiocyanate-silica gel (Boom et al., 1990). DNA concentration was calculated by spectrophotometry by taking the optical density at $280 \mathrm{~nm}$.

PCR and PCR-RFLP condition: Amplified region is located in the intron 2 (422 bp) between two exons of leptin. The genomic bovine leptin sequence which consists of three exons was obtained from Gene Bank (accession number U50365). The following primers were used for amplification of the product.

\section{Forward: 5'-CTGGAGTGGCTTGTTATTTTCTTCT-3'} Reverse: 5'-GTCCCCGCTTCTGGCTACCTAACT-3'

Amplification reaction was carried out with $100 \mathrm{ng}$ of DNA in a $25 \mu \mathrm{L}$ total volume containing $1 \times \mathrm{PCR}$ buffer; $2.5 \mathrm{mM} \mathrm{Mgcl}_{2}$; dNTPs, $100 \mu \mathrm{M}$ of each; $0.5 \mu \mathrm{M}$ of each primer and 1 unit of Taq DNA polymerase. The thermal cycling profile consist of an initial denaturation step of 3 min at $94^{\circ} \mathrm{C}$ followed by 35 cycles $45 \mathrm{sec}$ at $94^{\circ} \mathrm{C}$, $45 \mathrm{sec}$ at $60^{\circ} \mathrm{C}, 45 \mathrm{sec}$ at $72^{\circ} \mathrm{C}$ and final extension step of $10 \mathrm{~min}$ at $72^{\circ} \mathrm{C}$. Electrophoresis was carried out on $2 \%$ agarose gel with $5 \mu \mathrm{L}$ of PCR product. Then PCR products were digested with $5 \mathrm{U}$ of BstMB1 enzyme for $6 \mathrm{~h}$ at $65^{\circ} \mathrm{C}$. Restriction fragments were revealed by gel electrophoresis on $8 \%$ acrylamide gel and visualized with silver staining. pUC19 and M100 bp were used as molecular weight markers. Genotypic and alleleic frequencies of leptin gene were analyzed using the Popgen 1.32 computer program.

Statistical analysis: The growth and age at conception data were analyzed by analyzing standard least square within mixed models using JMP software (version 4.0.4; SAS Institute Inc, NC. USA). The model contained the effects of genotype and sires nested in the genotype. The milk production during 4 months of lactation and also cumulative milk production in the first 60 and 100 days of lactation were analyzed by analyzing standard least square within mixed models using JMP software (version 4.0.4; SAS Institute Inc, NC. USA). The model contained the effects of genotype, sires nested in the genotype, age and month of parturition.

Milking days was analyzed using a model containing the effects of genotype, sires nested in the genotype and interval between two consequent calving. Finally, the model for analyzing the days open data contained the effects of genotype, sires nested in the genotype, interval between parturition and second insemination and number of inseminations per pregnancy (Moussavi et al., 2006).

\section{RESULTS}

Allele frequency: One RFLP site in the intron 2 of the bovine leptin gene was detected. There were two BstMB1 sites in 422 bp fragments. The AA genotype PCR product exhibited two fragments of 390 and $32 \mathrm{bp}$. The BB genotype exhibited three fragments 302,88 and $32 \mathrm{bp}$. The AB genotype exhibited four fragments $390,302,88$ and 32 . Figure 1 shows the restriction patterns of the 3 genotypes $\mathrm{AA}, \mathrm{AB}$ and $\mathrm{BB}$. Chi-square test are shown in Table 1.

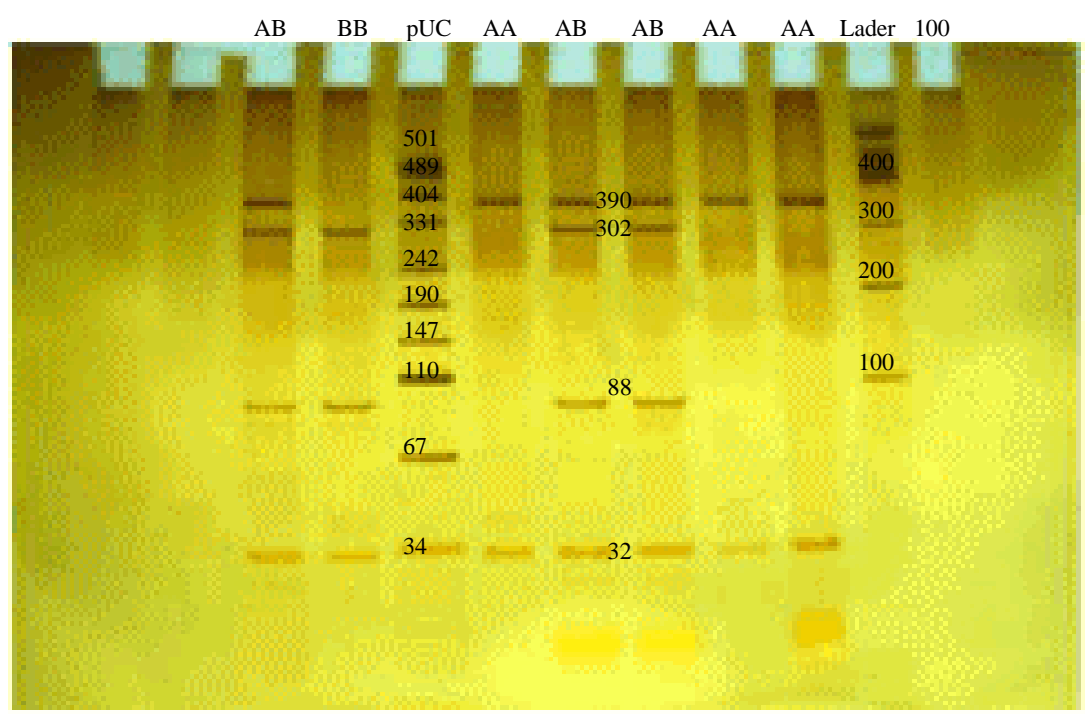

Fig. 1: Restriction patterns of the three genotypes $\mathrm{AA}, \mathrm{AB}$ and $\mathrm{BB}$ on $8 \%$ acrylamide gel 
Table 1: The genotypes, allele frequencies, Chi-square and number of individual with different genotype of BstMB1 polymorphisms in the intron 2 region of bovine leptin gene in Sistani and Brown Swiss cows

\begin{tabular}{lccccccl}
\hline & & \multicolumn{3}{c}{ Genotype frequency } & \multicolumn{3}{c}{ Allele frequency } \\
& $\begin{array}{l}\text { No. of } \\
\text { Bnimal }\end{array}$ & $-\mathrm{AA}$ & $\mathrm{AB}$ & $\mathrm{BB}$ & $\mathrm{A}$ & $\mathrm{B}$ & $\chi^{2}$-test \\
\hline Sistani & 103 & 0.77 & 0.22 & 0.01 & 0.88 & 0.12 & $0.188367^{\mathrm{NS}}$ \\
Brown Swiss & 104 & 0.64 & 0.35 & 0.01 & 0.82 & 0.18 & $2.63^{\mathrm{NS}}$ \\
\hline \multicolumn{2}{l}{$\mathrm{NS}=$ Non Significant, $\mathrm{p}<0.05, \mathrm{df}=2$}
\end{tabular}

Table 2: Effect of animal genotype on growth and age at conception traits in Sistani cows

\begin{tabular}{lcr}
\hline Traits & AA (LSM \pm SE) & AB (LSM \pm SE) \\
\hline Weight at 9 month (kg) & $117.80 \pm 0.99^{\mathrm{a}}$ & $133.85 \pm 1.630^{b}$ \\
Weight at 12 month (kg) & $140.28 \pm 1.19^{\mathrm{a}}$ & $155.80 \pm 1.740^{b}$ \\
Age at conception (day) & $1117.98 \pm 9.44^{\mathrm{a}}$ & $1154.78 \pm 15.07^{\mathrm{b}}$ \\
\hline
\end{tabular}

LSM = Least Squares Mean; ${ }^{a}$ The value traits in AA genotype; $\mathrm{SE}=$ Standard Error; ${ }^{b}$ The value traits in $\mathrm{AB}$ genotype

The frequency of allele A was 0.88 and 0.82 and for allele B was 0.12 and 0.18 in Sistani cows and Brown Swiss cows, respectively. There was only one animal with the BB genotype which was excluded from the analysis. Chi-square test shown populations were in Hardy-Weinberg equilibrium with respect to leptin gene.

Effect of leptin gene polymorphism on growth: The least squares mean, standard deviation for weight at 9 and 12 month in sistani cows were shown in Table 2. Cattles with $\mathrm{AB}$ genotype had higher weight at 9 and 12 month of age than the AA genotype $(\mathrm{p}<0.01)$.

Effect of leptin gene polymorphism on age at conception: The effects of leptin genotypes on age at conception in Sistani cows are shown in Table 2. In the age at insemination induce pregenancy, significant differences were found between genotypes. The $\mathrm{AB}$ genotype demonstrated the highest values for age at conception $(\mathrm{p}<0.05)$.

Effect of leptin gene polymorphism on milk production: The least squares mean, standard deviation for milk production during 4 months of lactation and cumulative milk production in the first 60 and 100 days of lactation in Brown Swiss cows were shown in Table 3.

Milk production during 5-9 months of lactation did not affect by animal genotype. While milk production during 4 month of lactation $(\mathrm{p}<0.05)$ and cumulative milk production in the first 60 and 100 days of lactation $(\mathrm{p}<0.01)$ affected by animal genotype. The genotype $\mathrm{AB}$ demonstrated the highest values for milk production $(\mathrm{p}<0.05)$.
Table 3: Effect of animal genotype on milk production traits

\begin{tabular}{|c|c|c|}
\hline$\underline{\text { Traits }}$ & $\mathrm{AA}(\mathrm{LSM} \pm \mathrm{SE})$ & $\mathrm{AB}(\mathrm{LSM} \pm \mathrm{SE})$ \\
\hline 1 month lactation (day) & $20.04 \pm 4.0200^{\mathrm{a}}$ & $33.70 \pm 5.380^{b}$ \\
\hline 2 month lactation (day) & $29.20 \pm 3.3700^{\mathrm{a}}$ & $39.12 \pm 3.580^{b}$ \\
\hline 3 month lactation (day) & $23.55 \pm 3.6500^{\mathrm{a}}$ & $33.66 \pm 2.910^{b}$ \\
\hline 4 month lactation (day) & $20.76 \pm 3.0300^{\mathrm{a}}$ & $28.93 \pm 2.420^{b}$ \\
\hline $\begin{array}{l}\text { Cumulative milk production } \\
\text { in the first } 60 \text { days of lactation }(\mathrm{kg})\end{array}$ & $1457.74 \pm 196.03^{\mathrm{a}}$ & $2242.24 \pm 262.41^{b}$ \\
\hline $\begin{array}{l}\text { Cumulative milk production } \\
\text { in the first } 100 \text { days of lactation }(\mathrm{kg})\end{array}$ & $2419.52 \pm 295.26^{a}$ & $3415.53 \pm 236.18^{b}$ \\
\hline
\end{tabular}

Table 4: Effect of animal genotype on days open and milk days

\begin{tabular}{lll}
\hline Traits & $\mathrm{AA}(\mathrm{LSM} \pm \mathrm{SE})$ & $\mathrm{AB}(\mathrm{LSM} \pm \mathrm{SE})$ \\
\hline
\end{tabular}

Days open $\quad 161.37 \pm 16.83^{\mathrm{a}} \quad 134.71 \pm 17.01^{\mathrm{b}}$

\begin{tabular}{lll} 
Milk days & $323.07 \pm 12.04^{\mathrm{a}}$ & $283.7 \pm 15.61^{\mathrm{b}}$ \\
\hline
\end{tabular}

LSM $=$ Least squares mean; $\mathrm{SE}=$ Standard Error; ${ }^{\mathrm{a}}$ The value traits in AA genotype; ${ }^{b}$ The value traits in $\mathrm{AB}$ genotype

Effects of leptin gene polymorphism on days open and milk days: The effects of leptin genotype on days open and milking days in Brown Swiss cows is shown in Table 4. Significant differences in the days open and milk days were found in between genotypes. The genotype $\mathrm{AB}$ demonstrated the highest values for days open $(p<0.01)$ and milk days $(p<0.05)$.

\section{DISCUSSION}

The present study showed allelic frequencies of 0.82 for A allele in Brown Swiss cows and 0.88 for A allele in Sistani cows. Similar results were reported by Liefers et al. (2002) in Holstein cows and Moussavi et al. (2006) in Iranian Holstein cows. The frequency of the A allele was reported 0.85 and 0.95 , respectively in the Liefers et al. (2002) and Moussavi et al. (2006) reports.

Association between polymorphism of leptin gene and growth, reproduction and milk production have indicated in several studies. For example Hale et al. (1998) suggested that the leptin gene may be useful as a marker of carcass traits in Angus cattle. Oprzadek et al. (2003) reported that AA genotype had the highest weight of carcass. Liefers et al. (2002) reported that AB genotype had higher milk production and body weight in comparison with $\mathrm{AA}$ genotype. Also, the $\mathrm{AB}$ genotype had higher feed intake than the AA genotype and produced $1.32 \mathrm{~kg}$ day $^{-1}$ more milk and consumed $0.37 \mathrm{~kg} \mathrm{day}^{-1}$ more food compared with the AA genotype.

In the present study, the association between the leptin genotypes and growth, age at conception and milk production in sistani cows and the association between the genotypes and milk production, days open and milking days in Brown Swiss cows were studied. The results showed that the $\mathrm{AB}$ genotype had best effects on growth, age at conception, milk production, days open 
and milking days. Similarly, Moussavi et al. (2006) evaluated the association of genetic differences in the bovine leptin gene and milk yield and reproduction in Iranian holstein cows.

They were detected a significant association between the $A B$ genotype and 305 day milk yield $(p<0.05)$. Also they had indicated that $\mathrm{AB}$ genotype leptin locus had a trend to better reproduction performance than the homozygous. The results of the and other studies demonstrate that the $\mathrm{B}$ allele can yield a higher milk production with a trend to better reproduction performance.

In the study, $\mathrm{AB}$ genotype had positive role in cattle growth, age at conception, milk production, days open and milking days. There are significant differences between the genotypes $\mathrm{AA}$ and $\mathrm{AB}$ in milk production during 4 month of lactation and cumulative milk production in the first 60 and 100 days of lactation $(p<0.05)$ and there were significant differences between the genotype $\mathrm{AA}$ and $\mathrm{AB}$ on days open $(\mathrm{p}<0.01)$ and milking days $(\mathrm{p}<0.05)$.

So, It seems that B allele is the favorable allele in economical traits in cattle. In addition to the region of leptin gene in this study, some research was carried out on another region of leptin gene. Nkrumah et al. (2005) reported association between SNP in the 5' untranslated promoter region of the bovine leptin gene with serum leptin concentration, growth, body weight, feed intake and carcass merit in hybrid cattle and it showed that animals with the TT genotype show 48 and $39 \%$ increases in serum leptin concentration and 39 and $31 \%$ increases in backfat thickness and 13 and $9 \%$ increases in marbling score compared with $\mathrm{CC}$ and $\mathrm{CT}$ genotypes, respectively.

\section{CONCLUSION}

It is concluded that the researchers showed allelic frequencies of 0.82 for a allele in Brown Swiss cows and 0.88 for A allele in Sistani cows. The results showed that the $A B$ genotype had best effects on growth, age at conception, milk production, days open and milking days in Sistani cows and Brown Swiss cows.

\section{ACKNOWLEDGEMENTS}

This study was supported by a Grant-in-Aid for Scientifc Research from the Ferdowsi University of Mashhad for my $\mathrm{MsC}$ dissertation. The researchers thank Dr. Nassiri Dr. Jorjani and Dr. Tahmoorespur for developing the concept and designing the experiments. The researchers are also grateful to Dr. Ghazanfari and Dr. Nobari for carrying out the experimental design.

\section{REFERENCES}

Block, S.S., W.R. Butler, R.A. Ehrhardt, A.W. Bell, M.E. Van Amburgh and Y.R. Boisclair, 2001. Decreased concentration of plasma leptin in periparturient dairy cows is caused by negative energy balance. J. Endocrinol., 171: 339-348.

Boom, R., C.J.A. Sol, M.M.M. Salimans, C.L. Jansen, P.M. Wertheim van Dillen and J. van der Noordaa, 1990. Rapid and simple method for purification of nucleic acids. J. Clin. Microbiol., 28: 495-503.

Buchanan, F.C., C.J. Fitzsimmons, A.G. van Kessel, T.D. Thue, D.C.W. Sim and S.M. Schmutz, 2002. Association of a missense mutation in the bovine leptin gene with carcass fat content and leptin mRNA levels. Genet. Sel. Evol., 34: 105-116.

Fruhbeck, G., S.A. Jebb and A.M. Prentice, 1998. Leptin: Physiology and pathophysiology. J. Clin. Physiol., 18: 399-419.

Fruhbeck, G., 2001. A heliocentric view of leptin. Proc. Nutr. Soc., 60: 301-318.

Haegeman, A., A. van Zeveren and L.J. Peelman, 2000. New mutation in exon 2 of bovine leptin gene. Anim. Genet., 31: 79-79.

Hale, C.S., W.O. Herring, G.S. Johnson, H. Shibuya, D.B. Lubahn and D.H. Keisler, 1998. Evaluation of the leptin gene as a possible marker of carcass traits in angus cattle. UMC Animal Sciences Departmental Report, pp: 25-27.

Hossner, K.L., 1998. Cellular, molecular and physiological aspects of leptin: Potential application in animal production. Can. J. Anim. Sci., 78: 463-472.

Houseknecht, K.L., C.A. Baile, R.L. Matteri and M.E. Spurlock, 1998. The biology of leptin: A review. J. Anim. Sci., 76: 1405-1420.

Konfortov, B.A., V.E. Licence and J.R. Miller, 1999. Resequencing of DNA from a diverse panel of cattle reveals a high level of polymorphism in both intron and exon. Mamm. Genome, 10: 1142-1145.

Lagonigro, R., P. Wiener, F. Pilla, J.A. Woolliams and J.L. Williams, 2003. A new mutation in the coding region of the bovine leptin gene associated with feed intake. Anim. Genet., 34: 371-374.

Liefers, S.C., R.F. Veerkamp and T. Vanderlene, 2002. Associations between leptin gene polymorphisms and production, live weight, energy balance, feed intake, and fertility in holstein heifers. J. Dairy Sci., 85: 1633-1638.

Liefers, S.C., R.F. Veerkamp, M.F.W. TePas, Y. Chilliard and T.V. Lende, 2003. Association of Leptin gene polymorphisms with serum leptin concentration in dairy cows. Mamm. Genome, 14: 657-663. 
Liefers, S.C., 2004. Physiology and genetics of leptin in periparturient dairy cows. J. Dairy Sci., 75: 175-185.

Moussavi, A.R.H., M. Ahouei, M. Nassiry and A. Javadmanesh, 2006. Association of leptin polymorphisms with production, reproduction and plasma glucose level in Iranian Holstein cows. Asian Aust. J. Anim. Sci., 19: 627-631.

Nkrumah, J.D., C. Li, J. Yu, C. Hansen, D.H. Keisler and S.S. Moore, 2005. Polymorphisms in the bovine leptin promoter associated with serum leptin concentration, growth, feed intake, feeding behavior and measures of carcass merit. J. Anim. Sci., 83: 20-28.
Oprzadek, J., K. Flisikowski, L. Zwierchowski and E. Dimnicki, 2003. Polymorphism at loci leptin, PIT1 and STAT5A and their association with growth feed conversion and carcass quality in black and white bulls. J. Anim Sci. Papers Rep., 21: 135-145.

Pomp, D., T. Zou, A.C. Clutter and W. Barendse, 1997. Rapid communication mapping of leptin to bovine chromosome 4 by linkage analysis of a PCR-based polymorphism. J. Anim. Sci., 75: 1427-1427.

Wilkins, R.J. and H.W. Davey, 1997. A polymorphic microsatellite in the bovine leptin gene. Anim. Genet., 28: $376-376$. 